\title{
Correction to: Introducing Rotavirus Vaccination in Nigeria: Economic Evaluation and Implications
}

\author{
Charles Ebuka Okafor ${ }^{1,2}$
}

Published online: 9 February 2021

(c) The Author(s) 2021

\section{Correction to: PharmacoEconomics Open https://doi.org/10.1007/s41669-020-00251-6}

In the Key Points for Decision Makers, the second point, which previously read:

"Early introduction of the vaccine will save the country about \$US8 per annum between 2021 and 2028 from Gavi support."

Should have read:

"Early introduction of the vaccine will save the country about \$US8 million per annum between 2021 and 2028 from Gavi support.”

The article has been corrected.
Open Access This article is licensed under a Creative Commons Attribution-NonCommercial 4.0 International License, which permits any non-commercial use, sharing, adaptation, distribution and reproduction in any medium or format, as long as you give appropriate credit to the original author(s) and the source, provide a link to the Creative Commons licence, and indicate if changes were made. The images or other third party material in this article are included in the article's Creative Commons licence, unless indicated otherwise in a credit line to the material. If material is not included in the article's Creative Commons licence and your intended use is not permitted by statutory regulation or exceeds the permitted use, you will need to obtain permission directly from the copyright holder. To view a copy of this licence, visit http://creativecommons.org/licenses/by-nc/4.0/.

The original article can be found online at https://doi.org/10.1007/ s41669-020-00251-6.

Charles Ebuka Okafor

charles.okafor@griffithuni.edu.au

1 Centre for Applied Health Economics, School of Medicine, Griffith University Queensland, 170 Kessels Road, Nathan, QLD 4111, Australia

2 Menzies Health Institute, Southport, QLD, Australia 